\title{
Chemical-genetic profile analysis in yeast suggests that a previously uncharacterized open reading frame, YBR26IC, affects protein synthesis
}

\author{
Md Alamgir ${ }^{1,2}$, Veronika Eroukova ${ }^{1,2}$, Matthew Jessulat ${ }^{1,2}$, Jianhua $\mathrm{Xu}^{3}$ and \\ Ashkan Golshani*1,2
}

Address: ${ }^{1}$ Department of Biology, Carleton University, 1125 Colonel By Drive, Ottawa, K1S 5B6, Canada, ${ }^{2}$ Ottawa Institute of Systems Biology, Carleton University, 1125 Colonel By Drive, Ottawa, K1S 5B6, Canada and ${ }^{3}$ College of Life Science, JiLin University, Changchun, 130012, PR China

Email: Md Alamgir - malamgir@connect.carleton.ca; Veronika Eroukova - erukova@gmail.com;

Matthew Jessulat - mjessula@connect.carleton.ca; Jianhua Xu - john_xu_bioinfo@yahoo.ca; Ashkan Golshani* - ashkan_golshani@carleton.ca

* Corresponding author

Published: 3 December 2008

BMC Genomics 2008, 9:583 doi:10.1/86/147|-2/64-9-583
Received: 26 June 2008

Accepted: 3 December 2008

This article is available from: http://www.biomedcentral.com/I47I-2/64/9/583

(c) 2008 Alamgir et al; licensee BioMed Central Ltd.

This is an Open Access article distributed under the terms of the Creative Commons Attribution License (http://creativecommons.org/licenses/by/2.0), which permits unrestricted use, distribution, and reproduction in any medium, provided the original work is properly cited.

\begin{abstract}
Background: Functional genomics has received considerable attention in the post-genomic era, as it aims to identify function(s) for different genes. One way to study gene function is to investigate the alterations in the responses of deletion mutants to different stimuli. Here we investigate the genetic profile of yeast non-essential gene deletion array (yGDA, 4700 strains) for increased sensitivity to paromomycin, which targets the process of protein synthesis.
\end{abstract}

Results: As expected, our analysis indicated that the majority of deletion strains (134) with increased sensitivity to paromomycin, are involved in protein biosynthesis. The remaining strains can be divided into smaller functional categories: metabolism (45), cellular component biogenesis and organization (28), DNA maintenance (2I), transport (20), others (38) and unknown (39). These may represent minor cellular target sites (side-effects) for paromomycin. They may also represent novel links to protein synthesis. One of these strains carries a deletion for a previously uncharacterized ORF, YBR26IC, that we term TAEI for Translation Associated Element I. Our focused follow-up experiments indicated that deletion of TAEI alters the ribosomal profile of the mutant cells. Also, gene deletion strain for TAEI has defects in both translation efficiency and fidelity. Miniaturized synthetic genetic array analysis further indicates that TAEI genetically interacts with 16 ribosomal protein genes. Phenotypic suppression analysis using TAEI overexpression also links TAEI to protein synthesis.

Conclusion: We show that a previously uncharacterized ORF, YBR26/C, affects the process of protein synthesis and reaffirm that large-scale genetic profile analysis can be a useful tool to study novel gene function(s).

\section{Background}

The number of available sequenced genomes has provided the biologists with a wealth of sequence informa- tion containing thousands of genes. Many of these genes code for proteins with multiple functions, some of which are not known. Others code for proteins of completely 
unknown function(s). To tackle this challenge, several large-scale methodologies, under the term functional genomics, have been developed which aim at revealing putative gene functions [1-3]. Due to its simple genetics, ease of manipulation, and conserved pathways, the yeast Saccharomyces cerevisiae, emerged as a model organism of choice for functional genomics [4]. While significant knowledge has been gained from various large-scale investigations, more experiments are needed to uncover the details of the functions of genes involved in different cellular processes. Exploring the function of individual proteins can greatly advance our understanding of the biology of a cell as a system.

Genes, which are involved in similar pathways often genetically, interact with each other. Therefore, one way to study gene functions is to investigate the interactions they make with each other [3]. This is based on the assumption that many eukaryotic pathways are functionally redundant. Thus, deletion of a gene may be tolerated with no phenotypic consequences. Inactivation of a second functionally related gene however, can cause sickness or even lethality. Therefore sickness of double mutants or "synthetic lethality" has been used to reveal novel gene functions. In simple terms, synthetic genetic array (SGA) analysis refers to large-scale investigation aimed at examining gene functions using double gene knockouts [3].

In addition to its role in functional genomics, availability of the yeast non-essential gene deletion array (yGDA, approximately 4700 strains) also provided the opportunity to investigate the cellular target sites of inhibitory compounds [5-7]. In this way, compounds with unknown cellular target sites are examined for their inhibitory effects on yGDA. The hypersensitive strains for genes with known functions are used to form a genetic profile for the activity of the target compound. This provides a fast and effective way to investigate cellular target sites of inhibitory compounds.

Similarly, inhibitory compounds with known modes of activity could be used to detect novel gene functions. This is not a novel concept and in various small-scale studies, numerous gene functions have been examined based on the increased sensitivity of their gene deletion strains to different compounds $[8,9]$.

As a final step in the gene expression pathway, the regulation of protein synthesis (translation) is used to control the expression of a variety of genes under different physiological conditions. For example, during cell division in the early steps of embryonic development [10,11], or during cellular transformation and cancer development [12], and as well, in stress conditions and apoptosis [13].
Even though the underlying principles of translation machinery have been the subject of vigorous investigations over the last few decades, details of all translation related proteins, protein complexes and pathways, as well as their communications and cross-talks with other cellular processes, have not been fully elucidated. Recently, several large-scale genomic investigations have uncovered numerous novel proteins thought to be functionally related to protein synthesis in S. cerevisiae [14-16], suggesting that there remain other undiscovered translation proteins.

Here, we applied a large-scale chemical-genetic profile analysis to identify yeast deletion strains that show increased sensitivity to aminoglycoside antibiotic paromomycin. This compound exerts its activity by targeting the process of protein synthesis. Focused follow-up experiments provided evidence that YBR261C, a previously uncharacterized open reading frame (ORF) which is identified by this screen, affects the process of protein synthesis in yeast.

\section{Results}

\section{The Initial screening and identification of TAEI}

In order to identify genes that affect protein synthesis, we screened the entire set of yGDA ( 4700$)$ for increased sensitivity to the aminoglycoside paromomycin. Paromomycin binds to the small ribosomal subunit of eukaryotic cells and compromises the translation fidelity [17]. Previously, it was shown that deletion of certain translation related genes caused increased sensitivity to paromomycin $[18,19]$. Therefore, we employed hypersensitivity to this drug as a way to detect novel gene candidates involved in translation. It should be noted that the deletion of certain translation related genes would cause increased resistance to paromomycin. This however, has not been investigated in our analysis.

We used yeast colony size reduction (CSR) as a tool to detect sensitivity to drug treatments. We have previously shown, that based on the parameters used by us (see Materials and Methods), CSR analysis can detect approximately $63 \%$ of the sensitive strains that are detected by a large-scale spot test (ST) analysis with no repeats [20]. Hence, there are a number of sensitive strains that would be missed by our analysis, that might otherwise be detected by ST. Similarly, the same large-scale ST analysis failed to detect $59 \%$ of the strains detected by CSR, which may represent novel/false-positives associated with CSR.

Here, we use sensitivity to paromomycin as a tool to detect protein synthesis related genes. A draw back for this, as well as other similar drug-based screening tests, is the detection of sensitive strains for those genes with no direct relation to the activity of the target drugs. A major 
source of such false-positives in our experiments may stem from those genes that play a role in general stress conditions. Multi-drug resistant genes represent some of these examples. For instance, it has been shown that the deletion of QDR1, a transporter gene and a member of efflux pumps, confers sensitivity to several unrelated drugs [21]. To increase the specificity of our selection procedure, we coupled our initial screen with a secondary search (based on the same parameters) for increased sensitivity to a second drug, which has no reported activity on the process of translation. For this purpose, we selected calcofluor white (CW), which is known to inhibit cell wall function by binding with chitin [22]. In this way, only those gene deletions that conferred sensitivity to paromomycin alone may represent meaningful positives.

As expected, our large-scale approach identified numerous translation genes such as TEF4 (translation elongation factor EF-1 gamma), HCR1 (a component of translation initiation factor 3), RPS18B (a ribosomal protein of small subunit), etc, which are sensitive to paromomycin and not to CW. The complete list of these genes is found in Additional file 1. The list of the genes that were sensitive to both paromomycin and CW is found in Additional file 2 . Of the 325 gene deletions sensitive to paromomycin alone, we found 42 genes that often appeared in our similar drug screenings using different bioactive compounds. These may represent false-positives and should be treated with caution. From the 325 total reported genes, 134 have been previously linked to the overall process of protein biosynthesis. 191 of them however, have never been connected in any way to this process, and therefore, may also represent novel/false-positive genes. These genes can be further classified into 5 smaller categories based on the cellular processes in which they participate, plus those which are unknown. As indicated in Figure 1, the minor categories are: metabolism with 45 genes, cellular component biogenesis and organization with 28, DNA maintenance with 21, transport with 20 and others with 38 genes. There were also 39 genes, which are unknown. An explanation for these smaller categories is that they may represent minor cellular target sites (sideeffects) for paromomycin. Alternatively, they may simply represent false-positives (see above). It is also possible that some of these genes might have novel roles during translation. In this case, they may represent communication bridges between different cellular processes and protein synthesis.

One of the previously uncharacterized ORF identified in this screen is YBR261C. There is no reported information about this ORF, except that it is computationally predicted to have a methyltransferases domain [23]. We therefore hypothesized that this might be a novel translation related gene. We termed this ORF, TAE1, for Transla- tion Associated Element 1, and subjected it to further analysis for its potential involvement in protein synthesis. ST analysis was used to confirm our large-scale observations (Figure 2). When the growth media was supplemented with a sub-inhibitory concentration of paromomycin $(13 \mathrm{mg} / \mathrm{ml})$, a deletion strain for TAE1 $(\operatorname{tae} 1 \Delta)$ showed a reduction in its growth pattern (Figure 2).

We then examined tae $1 \Delta$ strain for its increased sensitivity to 3-amino-1,2,4-triazole (3-AT) and cycloheximide. 3-AT can affect translation by altering the pool of amino acids in the cell [24]. Cycloheximide binds to large ribosomal subunit [25], and inhibits translation elongation by interfering with tRNA translocation [26]. It has previously been reported that deletion of certain genes that affect translation may confer sensitivity to multiple drugs that target translation. For example, deletion of Sfp1, which regulates ribosome biogenesis, confers increased sensitivity to both cycloheximide and paromomycin [27]. Shown in Figure 2, our spot test analysis indicated that in addition to paromomycin, tae $1 \Delta$ also showed increased sensitivity to 3-AT. Also some sensitivity for tae1s to cycloheximide was occasionally observed. However, due to irreproducibility of these observations, this sensitivity was presumed to be an artifact.

During the preparation of this manuscript, a new study was reported in which sensitivity of yeast gene deletion mutants to paromomycin were investigated using a heterozygous diploid yeast gene deletion mutant array [28]. This system is different from ours (haploid based), as its diploid mutant strains always carry a copy of the wild type genes and consequently show less obvious growth defects [29]. Of the 51 mutant strains that were identified by the authors as sensitive to paromomycin, 39 are shared between the two systems. Of these, 16 mutants were also identified by our haploid system. It is worth mentioning that tae $1 \Delta$ was not detected to have increased sensitivity to paromomycin in the heterozygous system, further highlighting the difference between the two systems [28].

\section{The effect of TAEI gene deletion on protein synthesis}

Translation genes can be involved in different aspects of translation. To examine the involvement of novel genes in protein synthesis, we divided translation into three general categories. Group one includes those genes that are associated with ribosome biogenesis, group two contains genes that alter translation efficiency, and group three is composed of the genes that affect translation fidelity. Depending on their molecular function(s), some translation genes may fall into none [30], one [27,31] or more [32] of these three categories. If TAE1 is involved in the process of translation, it might fall into one or more of these categories. 


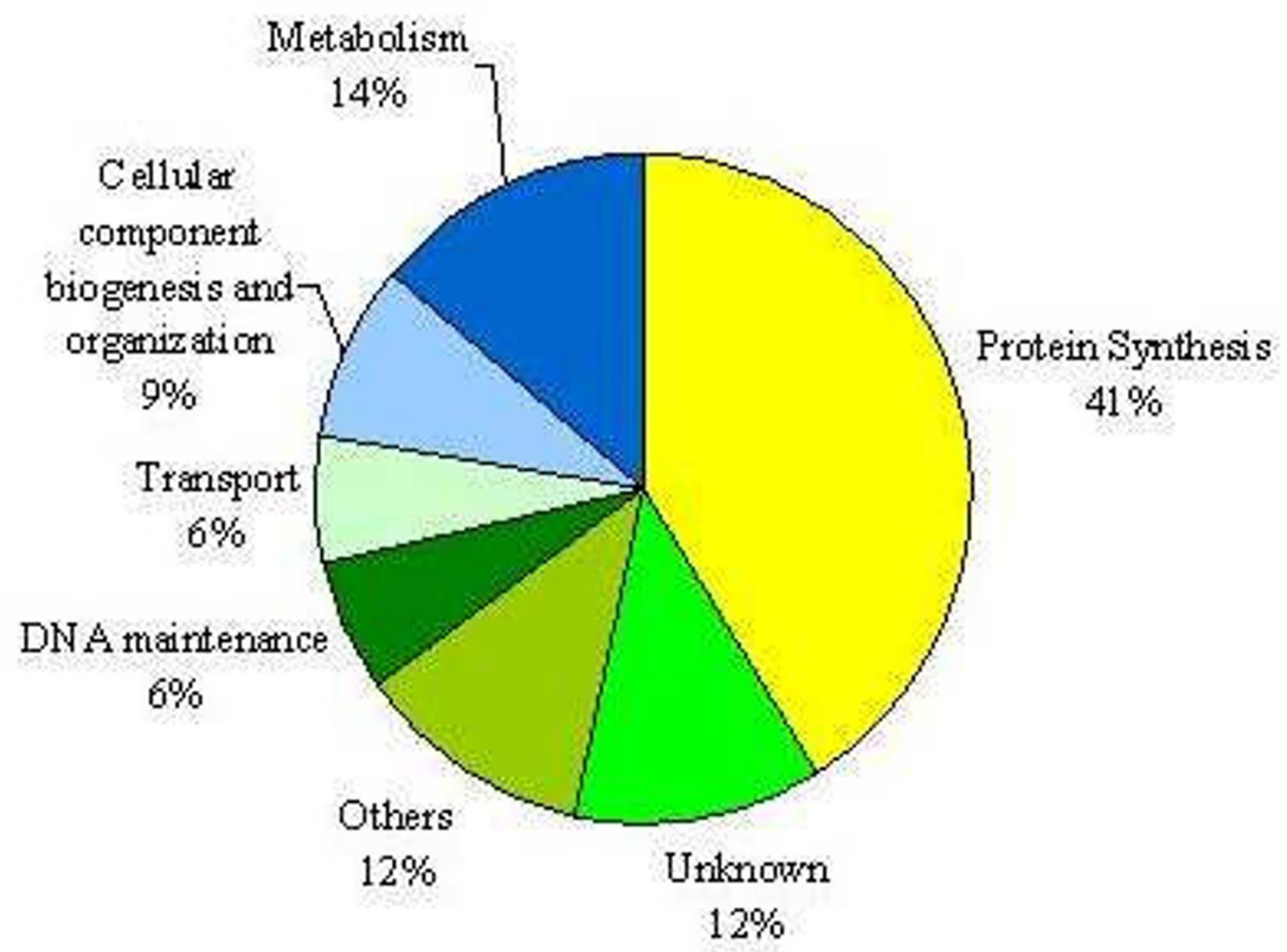

Figure I

Categories of gene deletion strains with increased sensitivity to paromomycin. Distribution of paromomycin hypersensitive yeast deletion strains in percentages according to their cellular functions.

\section{a) Involvement of TAEI in ribosome biogenesis}

Ribosome biogenesis and assembly is one of the most important processes in the protein synthesis pathway [33]. This process might be explained as the overall step that leads to the formation and assembly of functional ribosomes and includes regulation of pre-rRNA transcription, and its corresponding mechanisms, pre-rRNA processing, rRNA transport, rRNA maturation, ribosome assembly, etc. [34]. We therefore reasoned that depending on the molecular function(s) of TAE1, if this gene is involved in ribosome biogenesis or assembly, its deletion might result in the alteration of the profile of ribosomal subunits. To examine this possibility, ribosome profile analysis was performed. As expected, distinct 40S and 60S subunit peaks, as well as $80 \mathrm{~S}$ monosomes and polysome peaks (Figure 3 ) were detected in both the wild type and tae $1 \Delta$ strains. In addition, tae $1 \Delta$ strain showed a reduction in polysomes and corresponding increases in $80 \mathrm{~S}$ monosomes and 60S subunits (Figure 3). These alterations in ribosomal profile further indicate the involvement of TAE1 in protein synthesis.

\section{b) Involvement of TAEI in translation efficiency}

If TAE1 is involved in protein synthesis, then based on its molecular function(s), its deletion may alter the cell's efficiency s to synthesize proteins. To investigate this possibility, we used $\left.{ }^{35} \mathrm{~S}\right]$ methionine incorporations to measure the rate of total protein synthesis in different strains. As indicated in Figure 4A, it was observed that on average, tae1 $\Delta$ had a reduced level of [35S] methionine incorporation (approximately 22\%) compared to the control strain. To confirm this observation, we used an inducible $\beta$-galactosidase reporter construct (Figure $4 \mathrm{~B}$ ). It was observed that the deletion of TAE1 reduced the level of $\beta$ - 

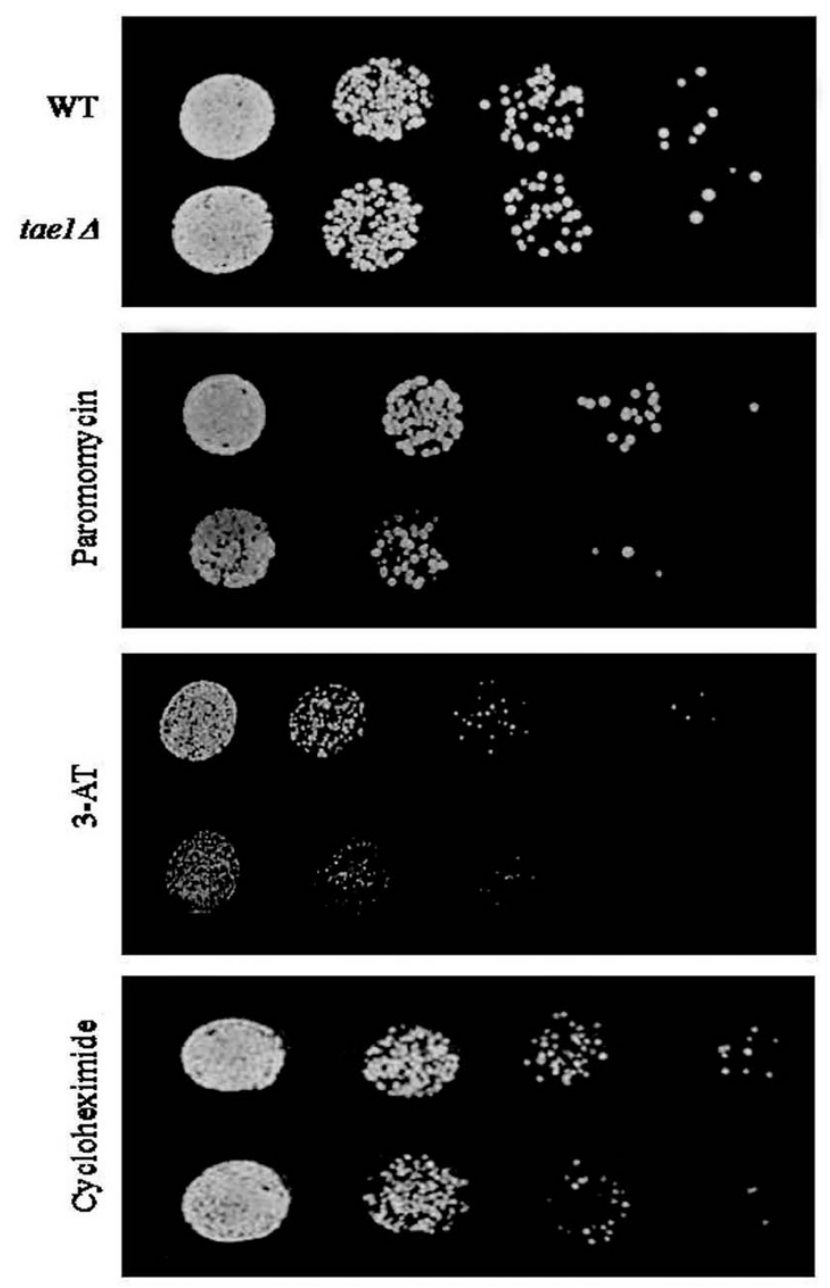

Figure 2

Increased sensitivity of tae I $\Delta$ to different translation inhibitory drugs. Deletion of TAEI confers increased sensitivity to different drugs that target translation. Decreasing numbers of wild type and mutant (tae $I \Delta$ ) yeast cells were spotted on solid media. The media was supplemented with sub-inhibitory concentrations of paromomycin (I3 mg/ml), 3AT $(22 \mathrm{mg} / \mathrm{ml})$, cycloheximide $(45 \mathrm{ng} / \mathrm{ml})$, or none (used as a control and shown in the top panel). Standard organic (YEPD) media was used for cycloheximide and synthetic complete (SC) media was used for paromomycin and 3-AT plates, and for the control plate shown here. Yeast cells were grown to mid-log phase and diluted 10-3 to $10-6$ folds. Twenty microliters of each dilution (gradually decreasing) was spotted onto the media and grown at $30^{\circ} \mathrm{C}$ for I-2 days. Deletion of TAEI conferred increased sensitivity to paromomycin and 3-AT. Occasional sensitivity to cycloheximide was assumed to be an artifact.

galactosidase synthesis from an inducible expression plasmid by approximately ten-folds (Figure 4B). These observations suggest that deletion of TAE1 may reduce the efficiency of protein synthesis in a cell, and provide further support that TAE1 affects protein synthesis.

\section{c) TAEI and Translation fidelity}

To make a functional protein, the fidelity of protein synthesis is maintained at almost all stages of translation. This fidelity is controlled during the start site selection and elongation when the mis-incorporation of the wrong amino acid may alter the integrity of the final product, as well as during termination, when a stop codon might be read through. If TAE1 is involved in translation, then it might be expected that based on its molecular function(s), the deletion of this gene may alter the fidelity of translation. Translation fidelity can be studied using specialized expression systems such as those that contain $\beta$ galactosidase expression cassettes, with premature stop codons [35]. In this investigation, we used plasmids pUKC817 and pUKC818 that contain lacZ genes carrying the nonsense codons UAA and UAG, respectively [35]. It was observed that the deletion of TAE1 resulted in an increased level of read through for the nonsense codons investigated, suggesting that in this deletion strain, the translation fidelity seem to be compromised (Figure 5A). For unknown reasons, the average values for $\beta$-galactosidase activities in the wild type strain, were systematically higher than expected.

Since differential levels of $\beta$-galactosidase activity in above experiments may also stem from altered levels of mRNAs, the content of $\beta$-galactosidase mRNAs of WT and tae $1 \Delta$ were investigated using Q-RT-PCR. We observed no significant variation in the amounts of these mRNAs (Figure $5 \mathrm{~B})$, which could explain the observed difference for the $\beta$-galactosidase activities. It was therefore concluded that the observed differences likely stem from translation read through. Altogether, the results indicate that the deletion of TAE1 seems to compromise translation fidelity, providing further evidence that TAE1 affects translation.

\section{TAEI genetically interacts with translation related genes}

The genes that are functionally related and are involved in similar pathways, often genetically interact with each other. Consequently, studying the genetic interactions of a novel gene is often used as a method to infer the function of that gene [36,37]. If TAE1 is a true translation gene, then it might be expected that TAE1 would genetically interact with certain known translation associated genes. To investigate this possibility, we examined the genetic interactions of TAE1 with a set of 384 genes, which are known or thought to be involved in translation. As indicated in Figure 6, it was observed that TAE1 genetically interacted with numerous translation related genes to produce sick phenotypes, which are classified as i) very sick, ii) sick, and iii) moderate. Lethal interactions were not considered. The interactions between TAE1 and transla- 


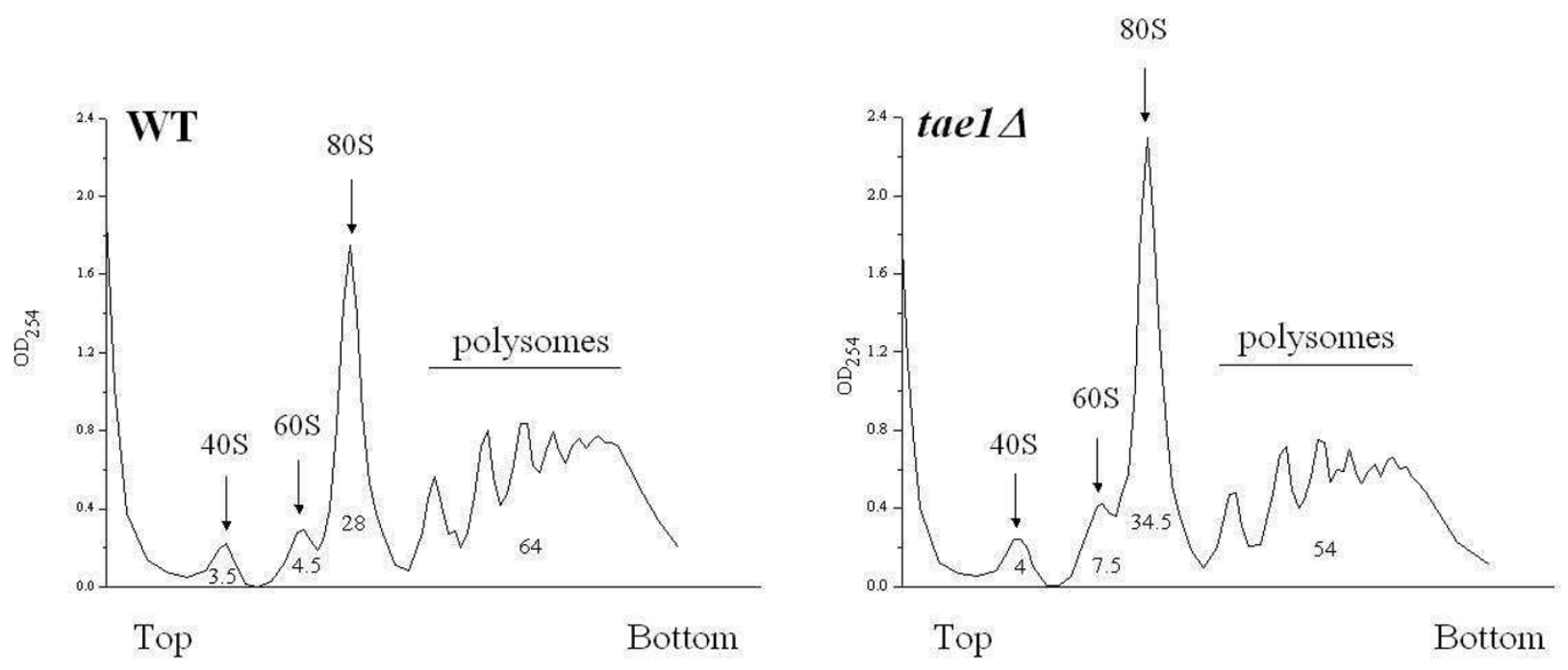

Figure 3

Ribosome profile analysis of yeast strains. Deletion of TAEI results in an overall decrease in polysomes, and a corresponding increase in $80 \mathrm{~S}$ monosome formations. There is also an increase in $60 \mathrm{~S}$ subunit in tael $\Delta$ cells. The large polysomes were collected at the lower half of the gradients (x-axis). The values under the peaks represent the areas under the curve for each peak, in percentages. Each experiment was repeated three times with similar outcomes.

tion related genes were further divided into three categories with ribosomal proteins forming the largest cluster (16 genes), followed by those involved in amino acids and protein production ( 7 genes), and those involved in
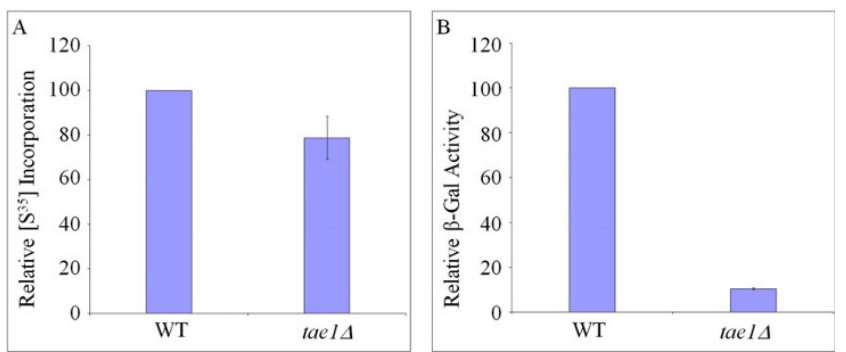

Figure 4

Protein synthesis profile in the presence and absence of Tae I. In (A) total protein synthesis is measured using [ $\left.{ }^{35} \mathrm{~S}\right]$ methionine incorporation. The average count for [ $\left.{ }^{35} \mathrm{~S}\right]$ methionine incorporation for wild type is $11,356,073( \pm$ $1,300,000$ ) counts, which is set to $100 \%$. In the absence of Tael protein, total protein production is reduced by approximately $22 \%$. t-test analysis indicates that the observed difference is statistically significant with the $p$-value of 0.05 . In (B) the efficiency of protein synthesis is measured using an inducible $\beta$-galactosidase reporter gene. The average $\beta$-galactosidase activity for wild type is $7.5 \mathrm{I}( \pm 0.6)$ units, which is set to $100 \%$. In the absence of Tael protein, an approximately tenfold reduction in $\beta$-galactosidase production is observed.
rRNA synthesis (2 genes). Descriptions of these genes are listed in Additional file 3. The fact that TAE1 genetically interacts with different translation associated genes provides further evidence for the involvement of TAE1 in the process of translation.

\section{Phenotypic suppression by the overexpression of TAEI}

To examine the cellular activity of Tae1 protein, we employed a high throughput approach, based on the phenotypic suppression of the gene deletion mutants that have known functions. Deletion of genes, which are involved in a specific pathway, may cause increased sensitivity to treatments that target the same process. Such hypersensitivities can be compensated by the overexpression of other genes with similar cellular functions. For example, it has previously been reported that the absence of Yku80, involved in telomere maintenance, causes increased sensitivity to elevated temperature. Overexpression of either Est2, a catalytic subunit of telomerase, or Tlc1, the RNA template component of telomerase, compensated for the absence of Yku80 and reversed the heat hypersensitivity of $y k u 80 \Delta$ [38].

Here, we investigated the activity of Tae 1 protein by examining the effect of its overexpression in suppressing hypersensitivities to antibiotics neomycin and streptomycin for the above 384 translation related gene deletion yeast strains. Like paromomycin, the antibiotics neomycin and 


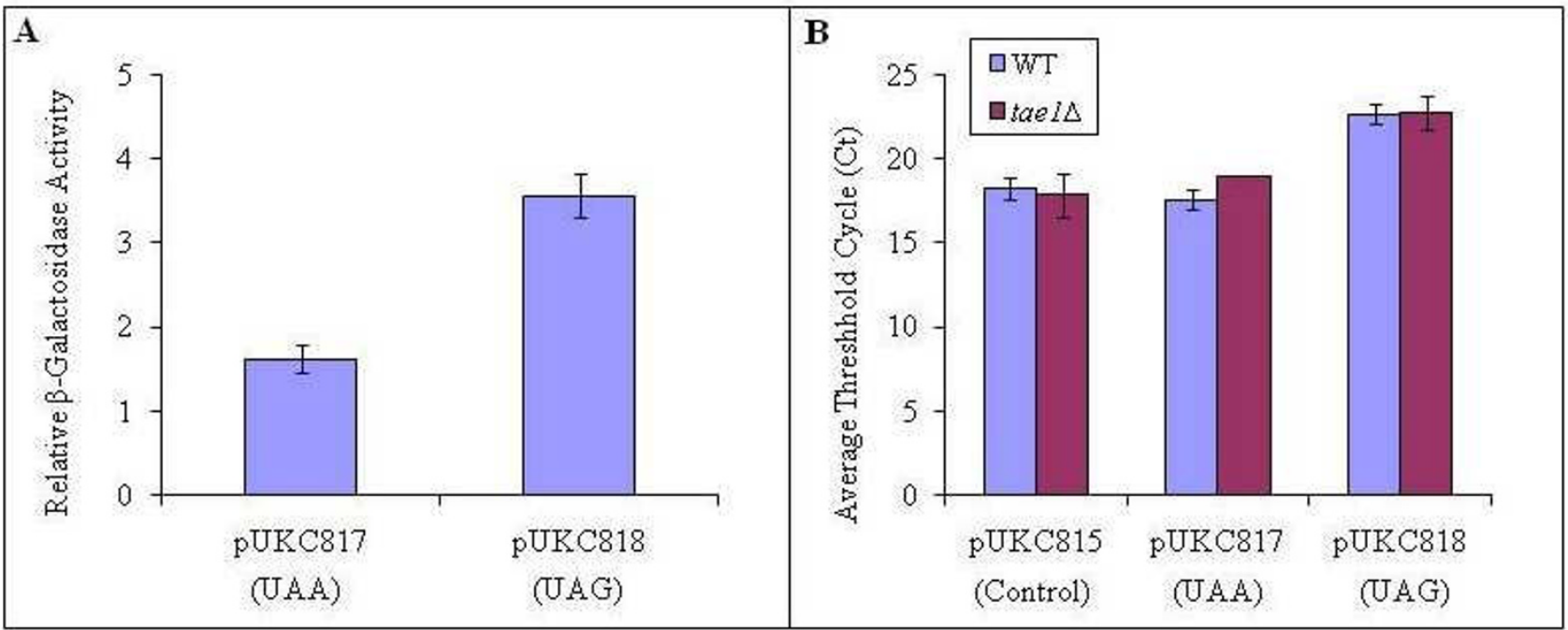

\section{Figure 5}

Effect of TAE I deletion on translation fidelity. (A) Deletion of TAEI resulted in increased levels of $\beta$-gal activity from the lac $Z$ reporters, pUKC8I7 and pUKC8I8, containing premature stop codons, UAA and UAG, respectively. The relative $\beta$-gal activity is determined by normalizing the activity of the mutant constructs (pUKC8I7 and pUKC8I8) to the control construct (pUKC8I5), and related to that obtained by the wild type strain (for example, the value for pUKC8I7/pUKC8I5 in tael $\Delta$ cells is related to that of pUKC8I7/pUKC8I5 in the wild type cells). The average $\beta$-gal activity for the wild type strain transformed with pUKC8I5 is 19.05 ( $\pm \mathrm{I}$.I) units. (B) Q-RT-PCR analysis indicates that alterations for the relative contents of LacZ mRNAs do not explain the difference in $\beta$-gal activities observed in $(A)$. The $C_{t}$ for the control and experimental samples were calculated from the threshold cycles. PUKC8I5 is the background construct without a premature stop codon and used as a control.

streptomycin, belong to the aminoglycoside family, which binds to ribosomes and disrupts translation [30]. We observed that overexpression of Tae1 protein, suppressed the drug sensitivity phenotypes for 28 deletion mutants of known translation genes (Figure 7). These 28 mutants showed sensitivity to treatment with neomycin and/or streptomycin. Tae1 overexpression however, reversed the observed drug sensitivities. These 28 gene deletion mutants can be categorized into two main groups of gene deletions for ribosomal proteins (17 genes), and those for translation control proteins (8 genes). Descriptions of the deleted genes are listed in Additional file 4. The fact that overexpression of Tae1 suppresses the phenotypes of deletion mutants for translation genes, further confirms an involvement for TAE1 in protein synthesis.

\section{Discussion}

Annotating gene functions has been an important aspect of post-genomic era. Identifying "which gene does what" is one of the fundamental tasks of systems biology, and sets the basis for understanding the biology of a cell. There are currently numerous uncharacterized genes with no known functions [4]. Moreover, there are numerous genes with multiple functions, some of which are not yet elucidated.
One approach to study gene function is to make gene knockouts, and observe the mutant cells' behavior to internal and/or external stimuli. Here, we screened the set of yGDA for sensitivity to paromomycin, which is known to target protein synthesis machinery. Due to an increased sensitivity, we hypothesized that a yeast gene deletion strain for TAE1 might affect the process of protein synthesis. We observed that the deletion of TAE1 reduced translation fidelity. This observation might be expected, since paromomycin is known to decrease the fidelity of translation. We also observed that deletion of TAE1 reduced the efficiency of translation, which is not necessarily coupled with translation fidelity, suggesting a wide-range effect for TAE1 on translation.

Tae1 protein is found in the cytoplasm and is bioinformatically predicted to contain an S-adenosylmethioninedependent methyltransferase activity. Certain members of this family of proteins have been shown to methylate different components of the translation machinery. For example, DIM1 and SPB1, which are nucleolar proteins involved in rRNA methylation; TRM proteins (such as TRM1 and TRM2), which are tRNA methyltransferases found in both cytoplasm and nucleus; and Mtq2, which methylates translation release factor SUP45 and is found 


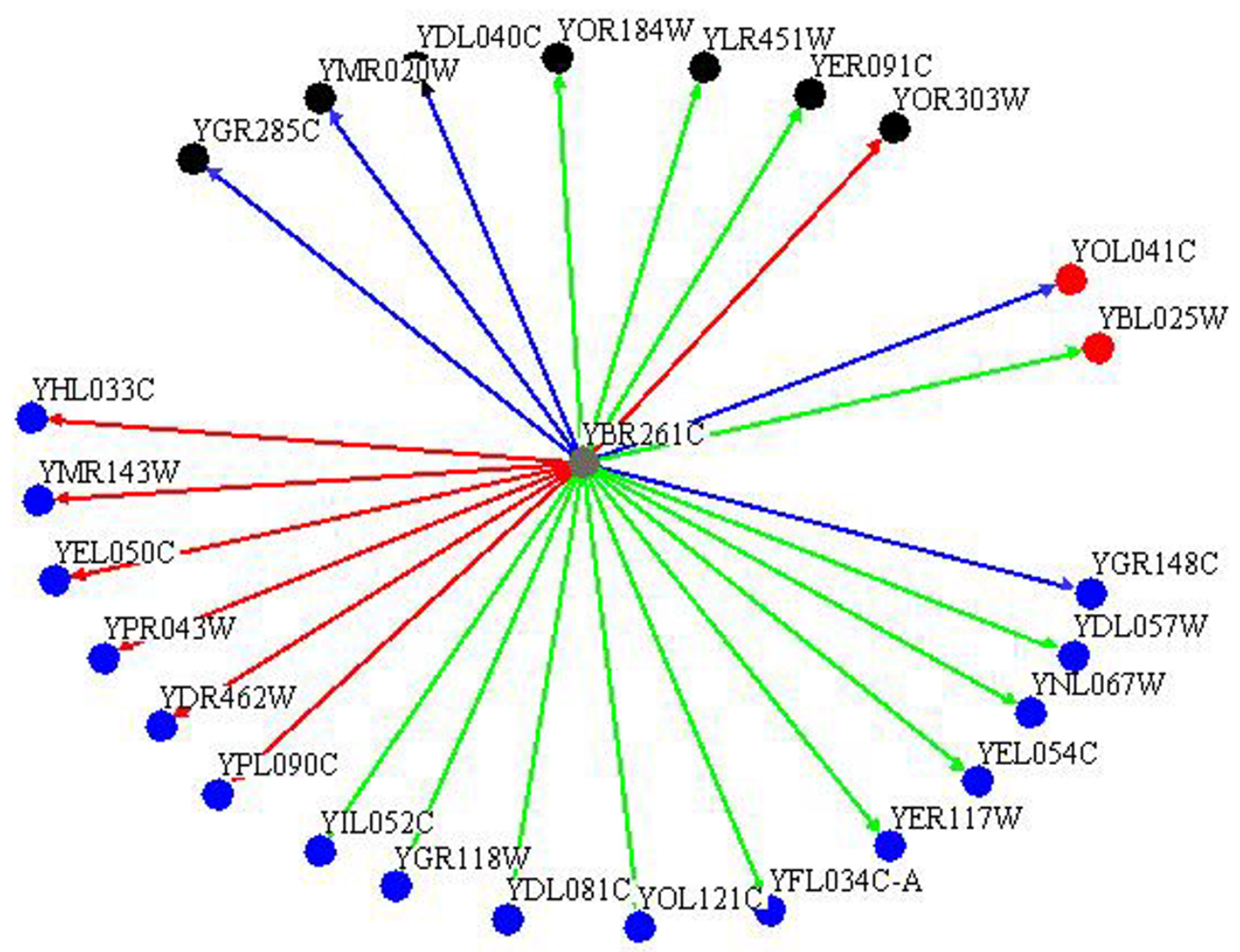

\section{Figure 6}

Genetic interaction of TAEI with translation genes. TAEI genetically interacts with numerous translations related genes to produce sick phenotypes. These interacting genes could be further divided into two major categories of ribosomal subunits ( 16 genes, blue circles), and amino acid and protein production ( 7 genes, black circles). The interacting genes shown in red circles are involved in ribosome biogenesis. Strong, moderate and weak interactions are shown by red, green and blue lines, respectively.

in both cytoplasm and nucleus. Presuming that Tae1 has a methyltransferase activity, we can assume that Tae1 affects translation by methylating a component of translation machinery.

In agreement with the observed reduction in translation efficiency for tae1 $\Delta$, our ribosomal profile analysis indicated an overall decrease in polysomes when TAE1 was deleted. In contrast, the 605 free subunits were specifically accumulated in tae $1 \Delta$ cells. Since $40 \mathrm{~S}$ and $60 \mathrm{~S}$ subunits are in equilibrium with $80 \mathrm{~S}$ monosomes, the increase in 60S subunit may indicate a defect in 40S biogenesis [39]. Assuming that TAE1 is a methyltransferase, a possible explanation is that TAE1 may effect $40 \mathrm{~S}$ biogenesis by either methylating $18 \mathrm{~S}$ rRNA directly, or by methylating a factor which affects $40 \mathrm{~S}$ biogenesis. In agreement with a role for TAE1 in ribosome biogenesis, TAE1 is found to be co-regulated with a number of ribosome processing factors in at least five different microarray analyses [40].

There is also an accumulation of $80 \mathrm{~S}$ monosomes in tae1 $\Delta$ cells, which may indicate a defect in translation initiation. Formation of defective ribosomes in the absence of TAE1 that cannot readily start elongation, may explain this accumulation of $80 \mathrm{~S}$ monosomes. Alternatively, it is possible that TAE1 might affect translation initiation by modifying a translation initiation protein. The latter explanation however, cannot explain the accumulation of 60S subunits. Regardless, further experiments are required to investigate details of the molecular activity of TAE1, and to identify its potential substrate(s).

Our genetic analysis revealed that TAE1 genetically interacts with a number of translation genes. In accord with the above-suggested function for TAE1 in ribosome subunit 


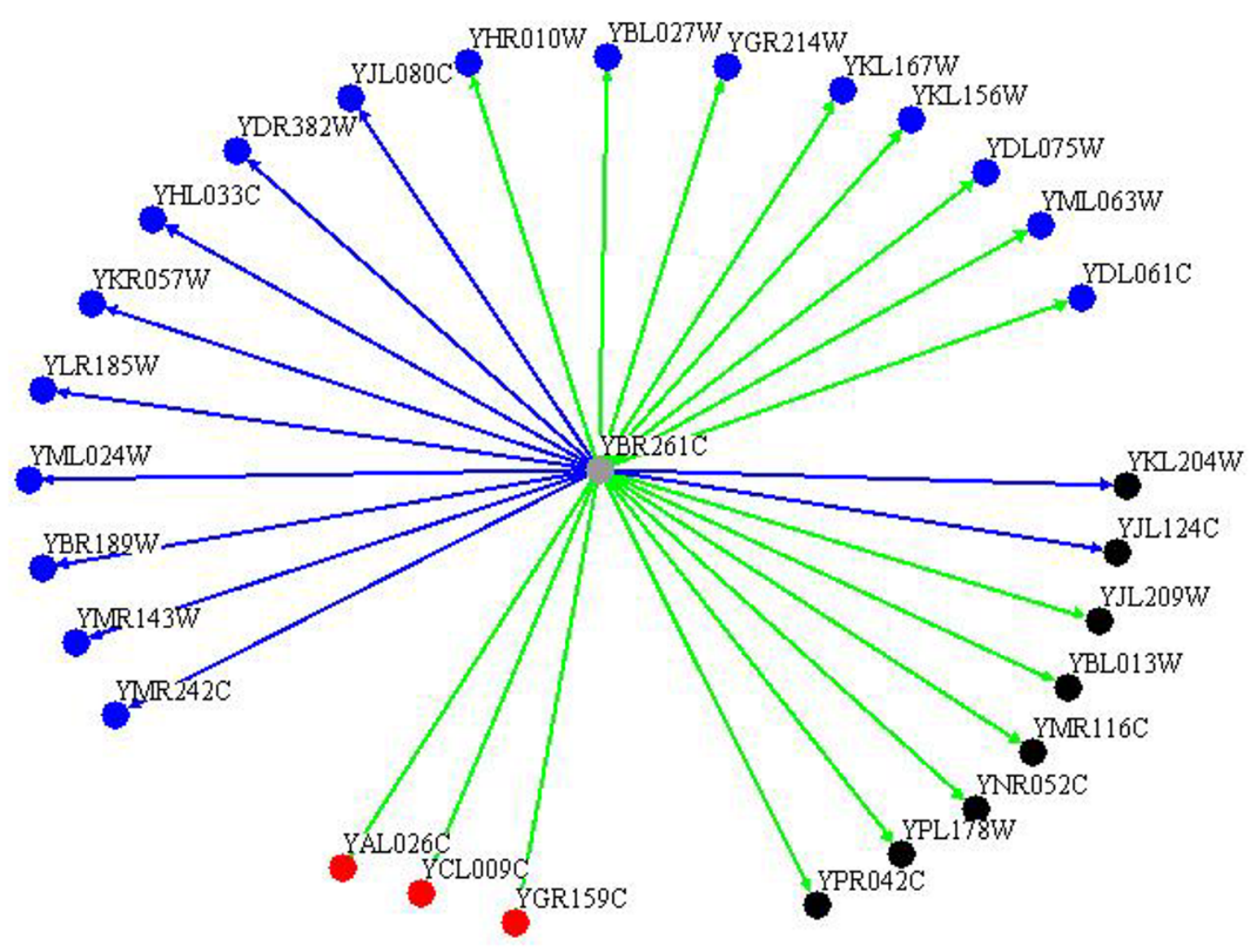

Figure 7

Overexpression of TAEI phenotypically suppresses the hypersensitivity of numerous translation genes against drug treatments. Overexpression of TAEI suppressed the inhibitory effects of neomycin and/or streptomycin for 28 yeast gene deletion strains. Among them, 17 genes belong to ribosomal proteins (blue circles) and 8 genes are involved in translation control (black circles). Red circles represent other genes. Complete and partial suppressions are shown by green and blue lines, respectively.

biogenesis, the majority of the observed interactions were found to be with ribosomal protein genes. Similarly, our phenotypic suppression analysis indicated a functional compensation by TAE1 overexpression, for the absence of 17 different ribosomal proteins against drug treatments. It should be noted that our genetic and phenotypic suppression analysis resulted in two different sets of proteins. This is expected, as genetic interaction analyses generally target the genes involved in different pathways within a process (redundant pathways), whereas phenotypic suppression analyses generally target genes within the same pathway. This data can be further used to study the detailed mechanism of TAE1 activity.

\section{Conclusion}

In conclusion, we investigated the sensitivity of yGDA to paromomycin, a drug that targets the process of transla- tion. One of the mutant strains identified by our screen was a deletion strain for a previously uncharacterized ORF, YBR261C, that here we termed TAE1, for Translation Associated Element 1. Our follow-up experiments indicated that the deletion of TAE1 caused reduction in translation efficiency and fidelity. Deletion mutant strain for TAE1 also had an altered ribosome profile. Our genetic analyses further confirmed the involvement of this gene in translation. Identification of a new gene in the process of translation suggests that there may exist other novel translation genes, which are yet to be discovered.

In addition, the large-scale phenotypic suppression analysis used here can set the path for similar approaches to investigate other gene functions. Furthermore, our data also reaffirms that large-scale chemical-genetic profile analysis can be successfully used in functional genomics. 


\section{Materials and methods}

\section{Drug resistance screening for yeast gene deletion array}

Sub-inhibitory concentrations of drugs were estimated from minimum inhibitory concentration (MIC) measurements based on a 96 varied concentration format as described in [41].

Approximately 4700 MATa haploid yeast, S. cerevisiae

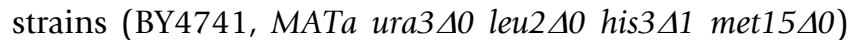
from the non-essential Gene Deletion Array (yGDA) described in $[3,5]$ was manually arrayed onto agar plates as previously described [36] in a 384 array format, with sub-inhibitory concentrations of paromomycin $(13 \mathrm{mg} /$ $\mathrm{ml}), \mathrm{CW}(40 \mu \mathrm{g} / \mathrm{ml})$ or without a drug (control). All plates were incubated at $30^{\circ} \mathrm{C}$ for $1-2$ days. The sensitivity of the gene deletion array to different drugs was investigated as before [36]. In brief, different strains are pinned on two plates, one with a sub-inhibitory concentration of a target drug and one without (used as a control) and incubated at $30^{\circ} \mathrm{C}$ for $1-2$ days. Digital images of plates were used to analyze the growth of individual colonies. For every plate the average size of colonies (white pixels) was calculated from equation (1).

$$
S_{\text {ave }}=1 / N \sum_{i=1}^{N} S_{i}
$$

where $N$ is the total number of colonies present in a given plate and $S_{i}$ is the area of object $i$. The deviation of area for each colony from the plate's average area was used for further analysis (relative growth) and was calculated by subtracting the scalar $S_{\text {ave }}$ from the plate's ordered area array explained in equation (2).

$$
\Delta S_{i}=S_{i}-S_{\text {avei }} i=1, \ldots, 384(16 \times 24=384)
$$

Relative colony size reduction of more than $30 \%$ was counted as a "hit". Each experiment was repeated three times. The gene deletion strains, which were "hits" in two or more of the three experiments, were counted as positives. Colonies with the highest two average reductions of $61 \%$ or more and $30-60 \%$ were defined supersensitives and sensitives, respectively.

ST test analysis was performed by growing yeast cell cultures in YEPD media to mid-log, following 10-3 to 10-6 folds dilutions. Twenty microliters of each dilution (gradually decreasing), was then spotted onto media containing the sub-inhibitory concentrations of the drugs (13 $\mathrm{mg} / \mathrm{ml}$ paromomycin, $22 \mathrm{mg} / \mathrm{ml} \mathrm{3-AT}$, and $45 \mathrm{ng} / \mathrm{ml}$ cycloheximide), and without (control). YEPD media was used for cycloheximide and SC media was used for paromomycin and 3-AT plates. The growth patterns were compared after $1-2$ days at $30^{\circ} \mathrm{C}$ as in [42].

\section{Gene expression analysis}

Constitutively expressed $\beta$-galactosidase (using pUKC815, pUKC817 and pUKC818) was assayed as described [43]. The units of enzyme activity were calculated as nanomoles of O-nitrophenyl- $\alpha$-D-galactopyranoside (OPNG) hydrolyzed per microgram of total protein [44]. All assays were conducted in triplicate. Induced $\beta$ galactosidase (using p416) was assayed as before [45].

In vivo [ $\left.{ }^{35} \mathrm{~S}\right]$ methionine incorporation was performed as previously described by Schwartz and Parker [46] with modifications. Briefly, yeast strains were grown to mid-log phase at $30^{\circ} \mathrm{C}$ in YEPD. The cells were harvested, resuspended in pre-warmed minimal medium lacking methionine, and supplemented with $10 \mu \mathrm{Ci} / \mathrm{ml}$ of $\left[{ }^{35} \mathrm{~S}\right]$ methionine. The cells were incubated for $1 \mathrm{~h}$ at $30^{\circ} \mathrm{C}$ and harvested by centrifugation. The samples were then washed with distilled water six times and collected $(1 \mu \mathrm{l}$ aliquot) on Whatman paper. The paper was air dried and exposed to storage phosphor screen for $1 \mathrm{~h}$. The counts were normalized to the final cell totals. Each experiment was repeated at least four times.

Total RNA was isolated using Bio-Rad RNA isolation kit. cDNA was constructed from $0.5 \mu \mathrm{g}$ of total RNA of each strain using iScript cDNA synthesis kit with SYBR green supermix (Bio-Rad) according to the instructions of the manufacturer. The quantification of mRNA was performed using real-time RT-PCR (Q-RT-PCR) on a RotorGene RG-300 from Corbett research. The PCR quantification and melting curves were generated using the Rotor gene 6 software. The amplification was performed: initial denaturation $95^{\circ} \mathrm{C}$ for $10 \mathrm{~min}$ followed by 40 cycles at $95^{\circ} \mathrm{C}$ for $30 \mathrm{~s}, 55^{\circ} \mathrm{C}$ for $20 \mathrm{~s}$ and $72^{\circ} \mathrm{C}$ for $20 \mathrm{~s}$ each with using 50 nmoles each of the forward (5'-ACTATCCCGACCGCCTTACT) and reverse (5'-TAGCGGCTGATGTTGAACTG) primers. The fluorescence was read at the end of each round of amplification. All standard dilutions and samples were run in triplicate. Quantification of mRNA were achieved by comparing the threshold cycle $\left(C_{t}\right)$ value of the sample RNA from deletion strain with the $C_{t}$ value of WT strain's standard RNA [47].

\section{Ribosome profile analysis}

Ribosome profiling was performed as described by Foani et al [48] with the following modifications. Wild type and mutant yeast cells were grown in YEPD at $30^{\circ} \mathrm{C}$ to a density of $2 \times 10^{7}$ cells $/ \mathrm{ml}$. Cycloheximide $(50 \mu \mathrm{g} / \mathrm{ml})$ was added to each culture and the cultures were quickly chilled in ice water bath. Cells were then centrifuged at $4000 \mathrm{rpm}$ for $4 \mathrm{~min}$ at $4{ }^{\circ} \mathrm{C}$ by sorvall SLA-1500 rotor. Cell pellets were resuspended in $10 \mathrm{ml}$ of ice-cold YA buffer (breaking buffer A: $10 \mathrm{mM}$ Tris- $\mathrm{HCl}[\mathrm{pH} 7.4], 100 \mathrm{mM}$ $\mathrm{NaCl}, 30 \mathrm{mM} \mathrm{MgCl}{ }_{2}$, cycloheximide $50 \mu \mathrm{g} / \mathrm{ml}$, heparin $200 \mu \mathrm{g} / \mathrm{ml}$ ) and centrifuged $4000 \mathrm{rpm}, 4 \mathrm{~min}$, at $4^{\circ} \mathrm{C}$ 
(Sorvall SS34 rotor), twice. The pellets were then resuspended in $0.5 \mathrm{ml}$ of YA buffer by vortex and stored at $80^{\circ} \mathrm{C}$ till the next day. Cells were then thawed on ice water bath. Glass beads were added and vortex for $20 \mathrm{sec}$ at maximum speed, 10 times with $30 \mathrm{sec}$ interval. The supernatants were centrifuged at $8,000 \times \mathrm{g}$ and $10,000 \times \mathrm{g}$ for 10 $\mathrm{min}$ and $30 \mathrm{~min}$, respectively. Twenty $\mathrm{OD}_{260}$ units of each supernatant were fractionated on $8-48 \%$ sucrose gradients containing $50 \mathrm{mM}$ Tris-acetate $(\mathrm{pH} 7.0), 50 \mathrm{mM}$ $\mathrm{NH}_{4} \mathrm{Cl}, 12 \mathrm{mM} \mathrm{MgCl}{ }_{2}$, and $1 \mathrm{mM}$ dithiothreitol. The extracts were then centrifuged for $2.5 \mathrm{hrs}$ at 39,000 rpm using a SW40-Ti rotor in a Beckman LE-80K at $4{ }^{\circ} \mathrm{C}$. The ribosome profiles were analyzed from the collected gradient solutions by monitoring the absorbance at $254 \mathrm{~nm}$. Each experiment was repeated three times with similar results.

\section{Genetic interaction and phenotypic suppression analysis}

Genetic interactions between TAE1 and a set of yeast gene deletion strains for 384 genes known or thought to be involved in translation were assessed by synthetic genetic miniarray profiling as discussed in [49] and the colony growth differences were assessed as in [20]. Possible synthetic sick interactions were confirmed by a spotting assay explained in [50]. We divided these interactions into strong, moderate and weak interactions based on their double mutant phenotypes of very sick, sick and slightly sick.

The TAE1 overexpression construct, pGAL1/10-GST$6 x H i s-Y B R 261 C$ is obtained from the yeast gene overexpression array explained in [51]. A compatible MAT $\alpha$

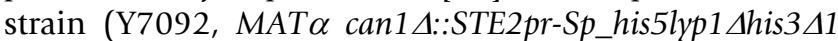
leu2 $\Delta 0$ ura3 $\Delta 0$ met15 $\Delta 0$ ) is then transformed with this construct and was crossed with a set of yeast gene deletion strains for 384 translation genes (see above) as in [49]. Sensitivity of yeast strains with or without TAE1 overexpression, against neomycin and streptomycin was performed using colony size measurements as discussed in [20]. Phenotypic complementations were divided into two categories of complete and partial suppressions. Partial complementation against both drugs is assigned partial. Complete complementation against one drug, regardless of the other, is assigned complete.

\section{Abbreviations}

yGDA: yeast non-essential Gene Deletion Array; ORF: open reading frame; Tae1: Translation Associated Element 1; 3-AT: 3-Amino-1, 2, 4-triazole.

\section{Authors' contributions}

All authors contributed to the conceptual development of the project. MA and VE conducted the experiments and analyzed the results. JX and AG administered the experi- ments. MA, MJ and AG wrote the manuscript. All authors read and approved the final manuscript.

\section{Additional material}

\author{
Additional file 1 \\ Supplemental Table 1. List of genes deletions, which are sensitive to \\ paromomycin. \\ Click here for file \\ [http://www.biomedcentral.com/content/supplementary/1471- \\ 2164-9-583-S1.xls]
}

\section{Additional file 2}

Supplemental Table 2. List of genes deletions, which are sensitive to both paromomycin and calcofluor white $(C W)$.

Click here for file

[http://www.biomedcentral.com/content/supplementary/14712164-9-583-S2.xls]

\section{Additional file 3}

Supplemental Table 3. Descriptions of translation related genes that genetically interact with TAE1.

Click here for file

[http://www.biomedcentral.com/content/supplementary/1471-

2164-9-583-S3.doc]

\section{Additional file 4}

Supplemental Table 4. Descriptions of translation related genes that are phenotypically suppressed by overexpression of TAE1, against treatment with neomycin and/or streptomycin.

Click here for file

[http://www.biomedcentral.com/content/supplementary/14712164-9-583-S4.doc]

\section{Acknowledgements}

We would like to give our sincere thanks to Julie Guzzo and Helena Friesen of Dr. Brenda Andrews's lab from University of Toronto for many discussions and assistance during the initial steps of SGA experiments and for their preliminary analysis. The authors would like to also thank Dr. Mick Tuite (University of Kent at Canterbury) and Dr. Terri Goss Kinzy (University of Medicine and Dentistry of New Jersey) for their generous gifts of pUKC-based plasmids. Many thanks go to Chris Kiani for excellent technical assistance and Joanna Freedman for excellent editorial work. This work was supported by the Natural Sciences and Engineering Research Council of Canada (NSERC). This work is dedicated to the loving memory of Abbas Golshani.

\section{References}

I. Ito T, Chiba T, Ozawa R, Yoshida M, Hattori M, Sakaki Y: A comprehensive two-hybrid analysis to explore the yeast protein interactome. Proc Natl Acad Sci USA 200I, 98(8):4569-4574.

2. Gavin AC, Bosche M, Krause R, Grandi P, Marzioch M, Bauer A, Schhultz J, Rick JM, Michon AM, Cruciat CM, et al.: Functional organization of the yeast proteome by systematic analysis of protein complexes. Nature 2002, 4|5(6868): |4|-| 47.

3. Tong AHY, Evangelista M, Parsons AB, Xu H, Bader GD, Pagé N, Robinson M, Raghibizadeh S, Hogue CWV, Bussey H, Andrews B, Tyers $M$, Boone C: Systematic genetic analysis with ordered arrays of yeast deletion mutants. Science 200I, 294:2364-2368.

4. Peña-Castillo L, Hughes TR: Why are there still over 1000 uncharacterized yeast genes? Genetics 2007, I76(I):7-14. 
5. Parsons $A B$, Lopez A, Givoni IE, Williams DE, Gray CA, Porter J, Chua G, Sopko R, Brost RL, Ho CH, Wang J, Ketela T, Brenner C, Brill JA, Fernandez GE, Lorenz TC, Payne GS, Ishihara S, Ohya Y, Andrews B, Hughes TR, Frey BJ, Graham TR, Andersen RJ, Boone C: Exploring the mode-of-action of bioactive compounds by chemical-genetic profiling in yeast. Cell 2006, I 26(3):6| |-625.

6. Lopez A, Parsons AB, Nislow C, Giaever G, Boone C: Chemicalgenetic approaches for exploring the mode of action of natural products. Prog Drug Res 2008, 66:237-27I.

7. Parsons AB, Brost RL, Ding H, Li Z, Zhang C, Sheikh B, Brown GW Kane PM, Hughes TR, Boone C: Integration of chemical-genetic and genetic interaction data links bioactive compounds to cellular target pathways. Nat Biotechnol 2004, 22(I):62-69.

8. Lesage G, Sdicu AM, Ménard P, Shapiro J, Hussein S, Bussey H: Analysis of beta-I,3-glucan assembly in Saccharomyces cerevisiae using a synthetic interaction network and altered sensitivity to caspofungin. Genetics 2004, 167(I):35-49.

9. Chloupková M, LeBard LS, Koeller DM: MDLI is a high copy suppressor of ATMI: evidence for a role in resistance to oxidative stress. J Mol Biol 2003, 33 I(I): I55-165.

10. Johnstone O, Lasko P: Translational Regulation and RNA Localization in Drosophila Oocytes and Embryos. Annu Rev Genet 200I, 35:365-406.

11. Kuersten S, Goodwin EB: The Power of the 3'UTR: Translational Control and Development. Nat Rev Genet 2003, 4(8):626-637.

12. Ruggero D, Pandolfi PP: Does the ribosome translate cancer? Nat Rev Cancer 2003, 3(3): 179-192.

13. Holcik M, Sonenberg N: Translation control in stress and apoptosis. Nat Rev Mol Cell Biol 2005, 6(4):3 I 8-327.

14. Peng WT, Robinson MD, Mnaimneh S, Krogan NJ, Cagney G, Morris Q, Davierwala AP, Grigull J, Yang X, Zhang W, Mitsakakis N, Ryan OW, Datta N, Jojic V, Pal C, Canadien V, Richards D, Beattie B, Wu LF, Altschuler SJ, Roweis S, Frey BJ, Emili A, Greenblatt JF, Hughes TR: A panoramic view of yeast noncoding RNA processing. Cell 2003, II 3(7):919-933.

15. Krogan NJ, Peng WT, Cagney G, Robinson MD, Haw R, Zhong G, Guo X, Zhang X, Canadien V, Richards DP, Beattie BK, Lalev A, Zhang W, Davierwala AP, Mnaimneh S, Starostine A, Tikuisis AP, Grigull J, Datta N, Bray JE, Hughes TR, Emili A, Greenblatt JF: Highdefinition macromolecular composition of yeast RNAprocessing complexes. Mol Cell 2004, I3(2):225-239.

16. Fleischer TC, Weaver CM, McAfee KJ, Jennings JL, Link AJ: Systematic identification and functional screens of uncharacterized proteins associated with eukaryotic ribosomal complexes. Genes Dev 2006, 20(10): I294-I307.

17. Fan-Minogue H, Bedwell DM: Eukaryotic ribosomal RNA determinants of aminoglycoside resistance and their role in translational fidelity. RNA 2008, 14: | 48-157.

18. Kressler $D$, de la Cruz J, Rojo M, Linder P: Fall $p$ is an essential DEAD-box protein involved in 40S-ribosomal-subunit biogenesis in Saccharomyces cerevisiae. Mol Cell Biol 1997, I 7( I 2):7283-7294.

19. Frigieri MC, João Luiz MVS, Apponi LH, Zanelli CF, Valentini SR: Synthetic lethality between elF5A and YptI reveals a connection between translation and the secretory pathway in yeast. Mol Genet Genomics 2008, 280:2I I-22I.

20. Memarian N, Jessulat M, Alirezaie J, Mir-Rashed N, Xu J, Zareie M, Smith M, Golshani A: Colony size measurement of the yeast gene deletion strains for functional genomics. BMC Bioinformatics 2007, 8: 117 .

21. Nunes PA, Tenreiro S, Sá-Correia I: Resistance and adaptation to quinidine in Saccharomyces cerevisiae: role of QDRI (YILI20w), encoding a plasma membrane transporter of the major facilitator superfamily required for multidrug resistance. Antimicrob Agents Chemother 200I, 45(5): I528-I534.

22. Hughes TR, Marton MJ, Jones AR, Roberts C], Stoughton R, Armour CD, Bennett HA, Coffey E, Dai H, He YD, Kidd MJ, King AM, Meyer MR, Slade D, Lum PY, Stepaniants SB, Shoemaker DD, Gachotte D, Chakraburtty K, Simon J, Bard M, Friend SH: Functional discovery via a compendium of expression profiles. Cell 2000, 102(I): $109-126$

23. Katz JE, Dlakiæ M, Clarke S: Automated identification of putative methyltransferases from genomic open reading frames. Mol Cell Proteomics 2003, 2(8):525-540.
24. Zhou W, Edelman GM, Mauro VP: Isolation and identification of short nucleotide sequences that affect translation initiation in Saccharomyces cerevisiae. Proc Natl Acad Sci USA 2003, I 00(8):4457-4462.

25. Leeds P, Wood JM, Lee BS, Culbertson MR: Gene products that promote mRNA turnover in Saccharomyces cerevisiae. Mol Cell Biol 1992, I 2(5):2165-2I77.

26. Obrig TG, Culp WJ, McKeehan WL, Hardesty B: The mechanism by which cycloheximide and related glutarimide antibiotics inhibit peptide synthesis on reticulocyte ribosomes. J Biol Chem 197I, 246(I): 174-I8I.

27. Fingerman I, Nagaraj V, Norris D, Vershon AK: Sfp I plays a key role in yeast ribosome biogenesis. Eukaryot Cell 2003, 2(5): $106 \mid-1068$.

28. Hillenmeyer ME, Fung E, Wildenhain J, Pierce SE, Hoon S, Lee W, Proctor M, St Onge RP, Tyers M, Koller D, Altman RB, Davis RW, Nislow C, Giaever G: The chemical genomic portrait of yeast: uncovering a phenotype for all genes. Science 2008 , 320(5874):362-365.

29. Deutschbauer AM, Jaramillo DF, Proctor M, Kumm J, Hillenmeyer ME, Davis RW, Nislow C, Giaever G: Mechanisms of haploinsufficiency revealed by genome-wide profiling in yeast. Genetics 2005, 169(4):1915-1925.

30. Walter F, Vicens $\mathrm{Q}$, Westhof E: Aminoglycoside-RNA interactions. Curr Opin Chem Biol 1999, 3(6):694-704.

31. louk TL, Aitchison JD, Maguire S, Wozniak RW: Rrblp, a yeast nuclear WD-repeat protein involved in the regulation of ribosome biosynthesis. Mol Cell Biol 200I, 2I(4): I260-I27I.

32. Dinman JD, Kinzy TG: Translational misreading: mutations in translation elongation factor I alpha differentially affect programmed ribosomal frameshifting and drug sensitivity. RNA 1997, 3(8):870-881.

33. Venema J, Tollervey D: Ribosome synthesis in Saccharomyces cerevisiae. Annu Rev Genet 1999, 33:26I-3II.

34. Rosado IV, Kressler D, de la Cruz J: Functional analysis of Saccharomyces cerevisiae ribosomal protein $\mathrm{Rpl} 3 \mathrm{p}$ in ribosome synthesis. Nucleic Acids Res 2007, 35( I 2):4203-42 I3.

35. Stansfield I, Akhmaloka , Tuite MF: A mutant allele of the SUP45 (SAL4) gene of Saccharomyces cerevisiae shows temperaturedependent allosuppressor and omnipotent suppressor phenotypes. Curr Genet 1995, 27(5):417-426.

36. Ideker T, Sharan R: Protein networks in disease. Genome Res 2008, 18:644-652.

37. Boone $\mathrm{C}$, Bussey $\mathrm{H}$, Andrews BJ: Exploring genetic interactions and networks with yeast. Nat Rev Genet 2007, 8(6):437-49.

38. Teo SH, Jackson SP: Telomerase subunit overexpression suppresses telomere-specific checkpoint activation in the yeast yku80 mutant. EMBO Rep 200I, 2(3): 197-202.

39. Vlásek L, Phan L, Schoenfeld LW, Valásková V, Hinnebusch AG: Related elF3 subunits TIF32 and HCRI interact with an RNA recognition motif in PRTI required for elF3 integrity and ribosome binding. EMBO J 200I, 20:89I-904.

40. Saccharomyces Genome Database [http://www.yeastge nome.org/]

41. Galván IJ, Mir-Rashed N, Jessulat M, Atanya M, Golshani A, Durst T, Petit P, Amiquet VT, Boekhout T, Summerbell R, Cruz I, Arnason JT, Smith ML: Antifungal and antioxidant activities of the phytomedicine pipsissewa, Chimaphila umbellata. Phytochemistry 2008, 69(3):738-746.

42. Anderson JB, Sirjusingh C, Parsons AB, Boone C, Wickens C, Cowen LE, Kohn LM: Mode of selection and experimental evolution of antifungal drug resistance in Saccharomyces cerevisiae. Genetics 2003, 163(4): 1 287-1298.

43. Lucchini G, Hinnebusch AG, Chen C, Fink GR: Positive regulatory interactions of the HIS4 gene of Saccharomyces cerevisiae. Mol Cell Biol 1984, 4(7): 1326-1333.

44. Shenton D, Smirnova JB, Selley JN, Carroll K, Hubbard SJ, Pavitt GD, Ashe MP, Grant CM: Global translational responses to oxidative stress impact upon multiple levels of protein synthesis. | Biol Chem 2006, 28 I(39):290 I I-2902 I.

45. Krogan NJ, Kim M, Tong A, Golshani A, Cagney G, Canadien V, Richards DP, Beattie BK, Emili A, Boone C, Shilatifard A, Buratowski S, Greenblatt ]: Methylation of histone $\mathrm{H} 3$ by Set 2 in Saccharomyces cerevisiae is linked to transcriptional elongation by RNA polymerase II. Mol Cell Biol 2003, 23( I 2):4207-42 I8. 
46. Schwartz DC, Parker R: Mutations in translation initiation factors lead to increased rates of deadenylation and decapping of mRNAs in Saccharomyces cerevisiae. Mol Cell Biol 1999, 19(8):5247-5256.

47. Yu S, Vincent A, Opriessnig T, Carpenter S, Kitikoon P, Halbur PG, Thacker E: Quantification of PCV2 capsid transcript in peripheral blood mononuclear cells (PBMCs) in vitro. Vet Microbiol 2007, I 23(I-3):34-42.

48. Foiani M, Cigan AM, Paddon CJ, Harashima S, Hinnebusch AG: GCD2, a translational repressor of the GCN4 gene, has a general function in the initiation of protein synthesis in Saccharomyces cerevisiae. Mol Cell Biol I99I, I I(6):3203-32I6.

49. Schuldiner M, Collins SR, Thompson NJ, Denic V, Bhamidipati A, Punna T, Ihmels J, Andrews B, Boone C, Greenblatt JF, Weissman JS, Krogan NJ: Exploration of the function and organization of the yeast early secretory pathway through an epistatic miniarray profile. Cell 2005, I 23(3):507-519.

50. Tong AHY, Lesage G, Bader GD, Ding H, Xu H, Xin X, Young J, Berriz GF, Brost RL, Chang $M$, et al.: Global mapping of the yeast genetic interaction network. Science 2004, 303:808-8I3.

51. Sopko R, Huang D, Preston N, Chua G, Papp B, Kafadar K, Snyder M, Oliver SG, Cyert M, Hughes TR, Boone C, Andrews B: Mapping pathways and phenotypes by systematic gene overexpression. Mol Cell 2006, 2 I (3):319-330.

Publish with Bio Med Central and every scientist can read your work free of charge

"BioMed Central will be the most significant development for disseminating the results of biomedical research in our lifetime. "

Sir Paul Nurse, Cancer Research UK

Your research papers will be:

- available free of charge to the entire biomedical community

- peer reviewed and published immediately upon acceptance

- cited in PubMed and archived on PubMed Central

- yours - you keep the copyright

Submit your manuscript here:

http://www.biomedcentral.com/info/publishing_adv.asp
BiolMedcentral 